\title{
ADMINISTRASI SARANA PRASARANA
}

\author{
Nofita Sari \\ E-mail \\ :nofitasari91199@gmail.com
}

\begin{abstract}
ABSTRAK
Administrasi sarana prasarana merupakan proses penataan yang bersangkut dengan pengadaan, pendayagunaan serta pengelolaan sarana prasarana pendidikan agar proses pendidikan dapat berjalan dengan efektif dan efisien, dan juga proses administrasi sarana prasarana disini sebagai penunjang proses pembalajaran serta administrasi ini juga dibutuhkan peranan dari guru dimana guru sangat terkait dalam sarana prasarana agar proses pembelajaran dapat terjalankan dengan baik.
\end{abstract}

Kata kunci: Administrasi, sarana prasarana

\section{PENDAHULUAN}

Sarana dan prasarana merupakan hal yang sangat sangat penting dalam proses pembelajaran dan kelancaran serta kemudahan dalam pendidikan yang membutuhkan sarana dan prasarana

dan juga pemanfaatannya baik dari segi intensitas maupun kreatifitas dalam penggunaannya baik oleh siswa maupun guru. dalam proses belajar mengajar. Sarana pendidikan adalah

semua fasilitas yang diperlukan dalam proses belajar mengajar baik yang bergerak maupun tidak bergerak agar pencapaian tujuan pendidikan dapat berjalan dengan lancar, teratur, efektif dan efisien. dalam perkembangan dunia pendidikan saat ini setiap lembaga pendidikan baik formal maupun non formal berusaha untuk memberikan dan melengkapi fasilitas yang ada di lembagannya untuk memenuhi kebutuhan semua warga sekolah baik itu guru, staf-staf, peserta didik dan orang tua murid. Proses belajar mengajar dapat meningkat dengan didukung adanya sarana dan prasarana yang memadai.

Sarana pendidikan merupakan sarana penunjang bagi proses belajar mengajar. hal ini merupakan faktor yang harus diperhatikan oleh sebuah lembagapendidikan. 


\section{TEORI DAN PEMBAHASAN}

A. Pengertian Administrasi

Sarana dan Prasarana

Pendidikan Administrasi

sarana dan prasarana pendidikan memiliki peranan penting dalam menunjang proses belajar mengajar di sekolah. Oleh karena itu di setiap sekolah dibutuhkan pelaksanaan administrasi sarana dan prasarana pendidikan yang baik.

Ary H. Gunawan (1996:

114) menyebutkan bahwa :

Administrasi Sarana dan Prasarana Pendidikan merupakan seluruh proses kegiatan yang direncanakan dan diusahakan secara sengaja dan bersungguh-sungguh serta pembinaan secara kontinu terhadap benda-benda pendidikan, agar senantiasa siap pakai dalam proses belajar mengajar sehingga proses belajar mengajar semakin efektif dan efisien guna membantu tercapainya tujuan pendidikan yang telah ditetapkan.

Berdasarkan pendapat di atas, dapat ditarik kesimpulan bahwa pengertian administrasi sarana dan prasarana pendidikan adalah serangkaian kegiatan perencanaan hingga penghapusan sarana dan prasarana dalam suatu lingkungan lembaga pendidikan agar proses belajar mengajar berjalan dengan efektif dan efisien sehingga dapat mencapai tujuan pendidikan.

Tujuan Administrasi Sarana dan Prasarana Pendidikan Dalam setiap kegiatan memiliki tujuan yang dilakukan sebagai landasan, agar kegiatan tersebut dapat terealisasi sehingga tujuan yang sudah ditentukan dapat tercapai tepat waktu.

Secara umum, tujuan administrasi sarana prasarana pendidikan adalah memberi layanan secara profesional di bidang sarana prasarana pendidikan dalam rangka terselenggaranya proses pendidikan secara efektif dan efisien.

Menurut Ary H. Gunawan (1996: 116) kegiatan sarana dan prasarana pendidikan meliputi:

1) Perencanaan pengadaan barang

2) Prakualifikasi rekanan

3) Pengadaan barang

4) Penyimpanan, inventarisasi,

5) Pemeliharaan, rehabilitas

6) Penghapusan, penyingkiran

7) Pengawasan 
Menurut Hartati Sukirman, dkk (2009: 29) kegiatan administrasi sarana dan prasarana pendidikan meliputi :

1) Perencanaan (kebutuhan dan biaya), dan pengadaan

2) Penyimpanan dan penyaluran

3) Pendayagunaan

4) Pemeliharaan

5) Inventarisasi dan penghapusan

Dari pendapat di atas, dapat didimpulkan bahwa kegiatan administrasi sarana dan prasarana pendidikan meliputi perencanaan pengadaan sarana dan prasarana, pengadaan sarana dan prasarana, penyimpanan dan penyaluran sarana dan prasarana, pemeliharaan sarana dan prasarana, inventarisasi sarana dan prasarana, serta penghapusan sarana dan prasarana.

B. PERAN GURU DALAM ADMINISTRASI SARANA PRASARANA

Peran guru dalam administrasi sarana prasarana ialah dimulai dari perencanaan, pemanfaatan dan pemeliharaan, serta pengawasan penggunaan prasarana-sarana. Sebagai pelaksana tugas pendidikan, guru juga mempunyai andil dalam administrasi sarana dan prasarana pendidikan.
Dalam hal ini, guru lebih banyak berhubungan dengan sarana pengajaran, yaitu alat pelajaran, alat peraga, dan media pengajaran lainnya dibandingkan dengan keterlibatannya dengan prasarana pendidikan yang tidak langsungberhubungan. Dengan demikian sarana prasarana sangat diperlukan peranan guru, agar proses pembelajaran dapat berjalan dengan baik.

\section{PENUTUP}

Kesimpulan

Administrasi Sarana dan Prasarana pendidikan merupakan seluruh proses yang direncanakan dengan diusahakan secara sungguh-sungguh dalam pembinaan secar continu terhadap benda-benda pendidikan, agar membantu tercapainya proses pendidikan.

\section{DAFTARPUSTAKA}

Gunawan, Ary H. 2002. Administrasi Sekolah (Administrasi Pendidikan Mikro). Jakarta: Rineka Cipta. (http://pendidikanadministrasi. com/2012/02/administrasisaranaprasarana-pendidik 